Available online at http://jurnal.stmikroyal.ac.id/index.php/jurteksi

\title{
DETECT THE SIMILARITY OF DIGITAL IMAGES USING THE EIGENFACE METHOD
}

\author{
Alwin Fau $^{1 *}$, Fince Tinus Waruwu ${ }^{1}$ \\ ${ }^{1}$ Computer Science, Universitas Budi Darma \\ email: "alwinfau@gmail.com
}

\begin{abstract}
In today's technological developments, digital images are a medium that is often used to store a person's identity. Digital images are currently widely used for data security needs. On the other hand, images can also be used as a medium for tapping data. Today's digital media provide many things in manipulating and changing the information contained in these images. In this study, the authors conducted a study to examine similarities in digital images so that it could be seen whether the information was authentic or not. detecting image similarities can help find out information whether the image is the same as the original object or not. The method used in this research is the Eigen Face method. The face eigen method is a method that can be used to check and match the similarities of an image. With the eigenface value, Figure 1, Figure 2, Figure 3, it can be determined that with other eigenface values can be determined based on the eigenface matrix values obtained from each image. Based on the values obtained from Figures 1,2, and 3, it can be concluded that the eigenface method is able to present facial similarities with a presentation value of $80 \%$.
\end{abstract}

Keywords: Eigenface; Face Recognation; Images; Images Processing

\begin{abstract}
Abstrak: Dalam perkembangan teknologi saat ini, gambar digital merupakan media yang sering digunakan untuk menyimpan identitas seseorang. Gambar digital saat ini banyak digunakan untuk kebutuhan keamanan data. di sisi lain, gambar juga dapat digunakan sebagai media penyadapan data. Media digital saat ini menyediakan banyak hal dalam memanipulasi dan mengubah informasi yang terdapat pada gambar tersebut. Dalam penelitian ini penulis melakukan penelitian untuk menelaah kemiripan pada citra digital sehingga dapat diketahui apakah informasi tersebut otentik atau tidak. Mendeteksi kemiripan citra dapat membantu mengetahui informasi apakah citra tersebut sama dengan objek aslinya atau tidak. Metode yang digunakan dalam penelitian ini adalah metode Eigen Face. Metode eigen wajah merupakan metode yang dapat digunakan untuk mengecek dan mencocokkan kemiripan suatu citra. Dengan nilai eigenface, Gambar 1, Gambar 2, Gambar 3, dapat ditentukan bahwa dengan nilai eigenface lainnya dapat ditentukan berdasarkan nilai matriks eigenface yang diperoleh dari masing-masing citra. Berdasarkan nilai yang diperoleh dari Gambar 1, 2, dan 3, dapat disimpulkan bahwa metode eigenface mampu menghadirkan kemiripan wajah dengan nilai presentasi $80 \%$.
\end{abstract}

Kata kunci: Citra; Eigenface; Pengolahan Citra Digital; Pengenalan Wajah 
DOI: https://doi.org/10.33330/jurteksi.v7i2.962

Available online at http://jurnal.stmikroyal.ac.id/index.php/jurteksi

\section{INTRODUCTION}

Attendance is related to discipline, the cooperation of each employee. STMIK Budi Darma is one of the computer colleges located in North Sumatra and in under LLDIKTI region I which was established since its inception and does not yet have a face recognition application that can be used to record and find out the presence of every employee and lecturer. STMIK Budi Darma has adequate facilities, especially computers that can be used to collect personnel data. The process of data collection on the attendance of employees and lecturers is still carried out manually and will be calculated based on each lecture report of each lecturer in one semester. The data collection process which is carried out will raise a new problem in improving Human Resources (HR).

STMIK Budi Darma does not have an application that can be used to collect lecturer attendance data. Along with that, every employee or lecturer does not have a good performance history. At this time, every schedule and operational hours that have been determined by the college will not be achieved properly, due to Human Resources (HR). One of the negative impacts that will occur from the indiscipline of Human Data Sources (HR) is that the vision and mission of STMIK Budi Darma will be difficult to achieve properly. The facial recognition application will be more effective in the process of data collection of staff or lecturer attendance and can also make it easier to achieve a predetermined vision and mission. Through the facial recognition application that is built, it will help certain units in evaluating every performance of employees or lecturers. On the other hand, the application will help lecturers and employees to be more disciplined in every operational hour given by Higher Education.

The human face recognition system is a system that is not easy because humans have a variety of facial expressions, appearances, and poses. In addition, the light conditions, distance, and camera quality are a challenge to design a real-time facial recognition system with a high degree of accuracy. There are various types of facial recognition methods, including Eigenface, Fisherface, and Local Binary Patent Histograms (LBPH). This research was conducted to compare facial recognition methods between Eigenface, Fisherface, and LBPH in changes in brightness, facial expressions, and facial recognition accuracy [1].

There are several methods of facial recognition, namely neural networks, adaptive neuro fuzzy, and eigenface. Specifically in this study the method that will be explained is the eigenface method, and uses a web cam to capture images in real time. The advantage of this method is that the computation is very fast and simple compared to the use of methods that require a lot of learning, such as artificial network requirements. Broadly speaking, the process of this application is the camera to capture faces, then an RGB value is obtained. Using the initial processing, resize, RGB to Grayscale, and histogram equalization for light alignment. The eigenface method functions to calculate the eigenvalue, and the eigenvector that will be used as a feature in making recognition. From the experiments and tests carried out, the tool can recognize facial images with a success rate of up to $90 \%$ at a distance of $25 \mathrm{~cm}$ with an average success of $72.5 \%$. This proves this tool is quite good in face 
DOI: https://doi.org/10.33330/jurteksi.v7i2.962

Available online at http://jurnal.stmikroyal.ac.id/index.php/jurteksi

recognition [2].

Face recognition is a computer application structured using complex algorithms using mathematical and matricial techniques, which get the image in raster mode (digital format) and then process and compare pixel by pixel using different methods to get faster and reliable results, clear results it depends on the use of a fast computer to process this because of the large computational power in this algorithm. In this research, facial detection and face recognition testing is carried out based on several possible factors that can affect the accuracy of face detection and recognition. These factors include the influence of age, facial style, the addition of accessories and training data training. The test results show that the accuracy rate of face detection is $90 \%$ [3].

The ease in the all-electronic world is now being tried in a parking system, where the parking system will facilitate the user in determining the parking location, and with this system further development will be easier, can be developed in the parking reservation system and parking payment system using the money electronic. In making this system the researcher is supported by the eigenface method, wherein the process of this system will calculate between beginning which already inputs with new data which will be capture in real-time by the system. By using eigenface method the researcher is supported with matlab application to make prototype to do testing to system whether it really feasible to be a problem solving or even add a problem. In testing the system is done using 90 data that all different objects and also different region of time. All objects are taken directly from the parking location [4].

Face Recognition related research has been done by applying Eigenface method as a trigger to automatically turn on the car starter manual. In this study, it was revealed that the facial recognition system made has a success rate of $77 \%$ of 13 times the test on the state of light intensity worth 27 lux, and $67 \%$ of the 15 times the test on the state of light intensity worth 85 lux. Success rate of $75 \%$ at different angle of lighting conditions with the lighting of training data from 12 times the test. The system is capable of taking decisions for unrecognized face input with a success rate of $100 \%$ of 12 tests, and is able to recognize faces with the distance between the camera and the testers ranging from $80 \mathrm{~cm}-130 \mathrm{~cm} \mathrm{[5].}$

This stage uses the eigenface method. Eigenface is used to reduce the dimensions of the face vector to a simpler vector (eigen vector). Many of these facial recognition systems use the Eigenface method, because the Eigenface method can provide a good level of accuracy, the system is able to produce a success rate of $84.6 \%$ with FAR (False Acceptance Rate) $=16.2 \%$, FRR (False Rejection Rate) ) $=20 \%$ and EER (Equal Error Rate) $=0.3$. The advantage of using this facial recognition system is to minimize theft from unknown people to enter our homes or rooms that we limit.In this method, facial images are projected into a feature that has significant variations between known facial images. The eigenface is a significant feature, because it is a major component of a face image set for training. The Eigenface method will capture points on the image that cause variations to match the faces in the database that make them distinguishable [6]. 
DOI: https://doi.org/10.33330/jurteksi.v7i2.962

Available online at http://jurnal.stmikroyal.ac.id/index.php/jurteksi

\section{METHOD}

As for the methodology in this study are the stage of data collection analysis design or design system development and testing. parts related to the making of learning media. Problem analysis This research was conducted by two methods, namely descriptive methods and methods comparative. research (Library Research) This library research aims to take the explanation/information needed when carrying out the task research is carried out. at this stage the system design process will be carried out, starting with the presentation of the material, practice, games and simulations, input interface design, algorithm creation, and output interface creation.

1. Images

Image is a combination of points, lines, colors, and fields to create an imitation of an object, usually a physical or human object. Images are divided into two parts, namely images with two dimensions such as photographs and paintings, while those with three dimensions are like sculptures. In today's world, many applications can be used to produce an image, for example, images that are scanners, images from digital cameras, images from image microscopes, images from fingerprint reader applications, and images that are recorded from CCTV (Closed). Circuit Television). There is much software that can be used to perform and change patterns from digital images, such as CorelDraw, Photoshop, and so on, which can be used to process the digital image reader. CCTV cameras are electric devices that can generate and capture an image both indoors and outdoors by using a closed television signal. The discipline of digital image processing is very broad, covering digital signal processing techniques as well as techniques specific to images. A figure can be thought of as a function of $f(x, y)$ of two continuous variables $\mathrm{x}$ and $\mathrm{y}$. To be processed digitally, it must be sampled and converted into a number matrix. Because computers represent numbers using finite precision, these numbers must be quantized in order to be represented digitally. Digital image processing consists of manipulating such as precise numbers. Digital image processing is divided into several classes, namely image repair, image restoration, image analysis, and image compression

2. Image Processing

Digital image processing (digital image processing) is the manipulation and interpretation of images with the help of computers. Image processing is usually used to improve image quality, perform the process of retrieving information or descriptions of objects contained in the image, and perform data compression or reduction. Based on the type, an image can be classified into 2 types, namely continuous image and discrete image (digital image). Continuous images are obtained from optical systems that receive analog signals, such as humans and analog cameras, while discrete images (digital images) are generated through the process of digitizing continuous images, while further explanations regarding the two types of images are as follows [7]. Continuous image is a 2dimensional intensity function $\mathrm{f}(\mathrm{x}, \mathrm{y})$, while $\mathrm{x}$ and $\mathrm{y}$ are spatial coordinates, and $\mathrm{f}$ at point $(\mathrm{x}, \mathrm{y})$ is the brightness level of an image at a point. Discrete image or digital image is a continuous 
function of light intensity or degree of gray in a 2-dimensional plane which can be represented by $\mathrm{f}(\mathrm{x}, \mathrm{y})$, where $\mathrm{x}$ and $y$ represent the coordinates of the coordinates of the position of the pixel are located, and the value of $\mathrm{f}(\mathrm{x}, \mathrm{y})$ indicates the intensity (degree of gray) of the pixel or picture element at these coordinates. The pixel itself is the smallest unit or element of the image which occupies a position that determines the resolution of the image [8]

3. Face Recognition

Digital facial recognition technology or more commonly known as face recognition. In general how it works is with convert photos, sketches, and video images into a series of numbers, called a faceprint and then compare them with another series of numbers representing familiar faces. Broadly speaking, the facial image recognition process by the system can be divided into five stages, namely Detection, Position Recognition, Normalization, Coding, Comparison [9]

\section{Eigenface Method}

One way that can be used in computer vision is face recognition. There have been many methods that can be used to carry out the process including Eigenface and Fisherface. In this research, the Eigenface method has applied to automatic lock systems, The Python as the programming language and Raspberry Pi to store face databases using the OpenCV library [2]. The database used consists of 10 facial photos, each taken from 10 different facial positions. Based on the results testing, the design of automatic key system tools with face identification in 10 sampel works in 1 $\mathrm{m}$ for detection camera, need at least 1,5 second to respon and 5,2 second for camera recognition processing time [10]. The steps of the eigenface method are as follows [6]

a. Sample data by creating a set $S$ consisting of all training drawings $=(\Gamma 1, \Gamma 2 \ldots, \Gamma \mathrm{M}) \mathrm{S}=(\Gamma 1, \Gamma 2, \ldots .$. ГM)

b. The second step is to take the mean or middle value $(\Psi)$

$$
(\Psi)=\frac{1}{M} \sum_{n=1}^{m} \Gamma_{n}
$$

c. The third step is to find the difference $(\Phi)$ between the value of the trainning images $\left(\Gamma_{1}\right)$ and the middle value

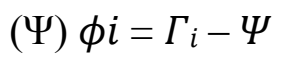

$d$. The fourth step is to calculate the covariance value

$$
\begin{aligned}
& \text { (C) } \mathrm{C}=\frac{1}{M} \sum_{n=1}^{m} \phi_{n} \phi_{n}^{T}=A A^{T} \\
& \mathrm{~L}=A A^{T} \\
& \mathrm{~L}=\phi_{n}^{T} \phi_{n}
\end{aligned}
$$

e. The fifth step calculates the eigenvalue $(\lambda)$ and eigenvector $(v)$ of the covariance matrix (C)

$$
C \mathrm{x} \mathrm{v}_{\mathrm{i}}=\lambda_{\mathrm{i}} \mathrm{x} \mathrm{v}_{\mathrm{i}}
$$

f. The sixth step after the eigenvector $(v)$ is obtained, the eigenface $(\mu)$ can be found with

$$
\mu_{\mathrm{i}}=\sum_{n=1}^{m} v_{i k} \phi_{k} \mathrm{~L}=1,,,,, \mathrm{M}
$$

\section{RESULT AND DISCUSSION}

There are several steps taken to carry out the facial recognition process, namely by preparing data and creating a matrix for each data in the database. Each value obtained will then take the mean or middle value and then find the difference between the image being trained and the mean value of the images. Calculate the value of the covariance matrix, calculate the eigenvalue and eigenvector, determine the eigenface value, and finally the identification process. For more details on the completion process.

a. Consists of data set $\mathrm{S}$ which consists of all training data 
DOI: https://doi.org/10.33330/jurteksi.v7i2.962

Available online at http://jurnal.stmikroyal.ac.id/index.php/jurteksi

At this stage, we compile a set of $\mathrm{S}$ matrix values where these values are taken from all the trained images $\left(\Gamma_{1}\right.$, $\left.\Gamma_{2}, \ldots \Gamma m\right)$. For example, in 4 facial data where each image data is taken in three directions and also different lighting. The data can be seen as in the table seen in table 1 .

Table 1. One Column Table Example

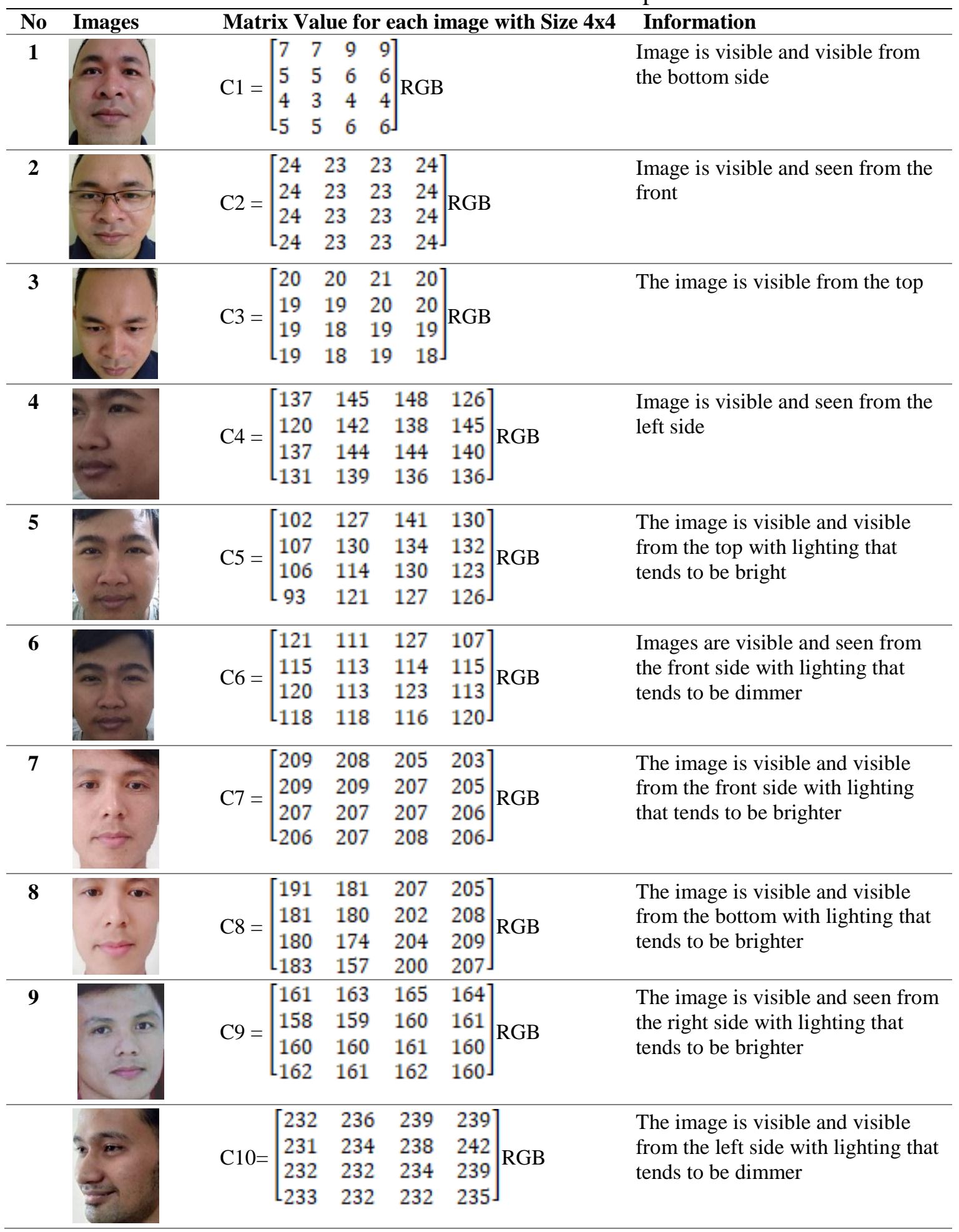


DOI: https://doi.org/10.33330/jurteksi.v7i2.962

Available online at http://jurnal.stmikroyal.ac.id/index.php/jurteksi

\begin{tabular}{llll}
10 & $\mathrm{C} 11=\left[\begin{array}{llll}215 & 214 & 214 & 213 \\
215 & 215 & 214 & 214 \\
215 & 215 & 214 & 214 \\
215 & 215 & 215 & 215\end{array}\right]$ RGB & $\begin{array}{l}\text { The image is visible and visible } \\
\text { from below the front with lighting } \\
\text { that tends to be brighter }\end{array}$ \\
\hline 11 & $\mathrm{C} 12=\left[\begin{array}{llll}205 & 205 & 205 & 205 \\
205 & 205 & 205 & 205 \\
205 & 207 & 206 & 204 \\
198 & 192 & 181 & 171\end{array}\right]$ RGB & $\begin{array}{l}\text { The image is visible and visible } \\
\text { from the front side with lighting } \\
\text { that tends to be brighter }\end{array}$
\end{tabular}

Table 1 is a table of the pixel values of each training data where this value can be used to test the eigenface method. The sample data taken from the training data is $4 \mathrm{x} 4$ pixels in size from each training data

b. The second step that needs to be done is to calculate the mean $(\Psi)$ value. Calculating the mean value can use the equation below

$$
\begin{aligned}
& (\Psi)=\frac{1}{M} \sum_{n=1}^{m} \Gamma_{n} \\
& (\Psi)=\frac{1}{a} \sum_{n=1}^{a} \Gamma_{n}=\frac{1}{a}\left[\begin{array}{llll}
7 & 7 & 9 & 9 \\
5 & 5 & 6 & 6 \\
4 & 3 & 4 & 4 \\
5 & 5 & 6 & 6
\end{array}\right]+ \\
& {\left[\begin{array}{llll}
24 & 23 & 23 & 24 \\
24 & 23 & 23 & 24
\end{array}\right]+\left[\begin{array}{llll}
20 & 20 & 21 & 20 \\
19 & 19 & 20 & 20
\end{array}\right]} \\
& \left.\begin{array}{llll}
24 & 23 & 23 & 24 \\
24 & 23 & 23 & 24
\end{array}\right]+\left[\begin{array}{llll}
19 & 19 & 20 & 20 \\
19 & 18 & 19 & 19
\end{array}\right. \\
& {\left[\begin{array}{llll}
24 & 23 & 23 & 24
\end{array}\right]\left[\begin{array}{llll}
19 & 18 & 19 & 18
\end{array}\right]} \\
& {\left[\begin{array}{llllllllllllllll}
7 & 7 & 9 & 9 & 5 & 5 & 6 & 6 & 4 & 3 & 4 & 4 & 5 & 5 & 6 & 6
\end{array}\right]} \\
& ==124 \begin{array}{lllllllllllllll}
23 & 23 & 24 & 24 & 23 & 23 & 24 & 24 & 23 & 23 & 24 & 24 & 23 & 24 & 24
\end{array} \\
& {\left[\begin{array}{llllllllllllllll}
20 & 20 & 21 & 20 & 19 & 19 & 20 & 20 & 19 & 18 & 19 & 18 & 19 & 18 & 19 & 18
\end{array}\right]} \\
& =\frac{1}{2}\left[\begin{array}{llllllllllllllll}
51 & 50 & 53 & 53 & 48 & 47 & 49 & 50 & 47 & 44 & 46 & 46 & 48 & 46 & 59 & 48
\end{array}\right]
\end{aligned}
$$

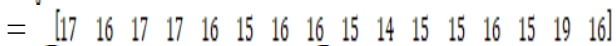

$$
\begin{aligned}
& =\left[\begin{array}{llll}
17 & 16 & 17 & 17 \\
16 & 15 & 16 & 16 \\
15 & 14 & 15 & 15 \\
16 & 15 & 19 & 16
\end{array}\right]
\end{aligned}
$$

c. Finding the difference between $(\phi)$ trainning images $(\Gamma 1)$ and the value $(\Psi)$, with the following equation:

$$
\begin{aligned}
& \phi_{i}=\Gamma_{1}-\Psi \\
& {\left[\begin{array}{llll}
7 & 7 & 9 & 9 \\
5 & 5 & 6 & 6 \\
4 & 3 & 4 & 4 \\
5 & 5 & 6 & 6
\end{array}\right]-\left[\begin{array}{cccc}
17 & 16 & 17 & 17 \\
16 & 15 & 16 & 16 \\
15 & 14 & 15 & 15 \\
16 & 15 & 19 & 16
\end{array}\right]} \\
& =\left[\begin{array}{cccc}
-10 & -9 & 8 & -8 \\
-11 & -10 & -10 & -10 \\
-11 & -11 & -11 & -11 \\
-11 & -10 & -13 & -10
\end{array}\right] \\
& \phi_{2}=\Gamma_{2}-\Psi
\end{aligned}
$$

$$
\begin{aligned}
= & {\left[\begin{array}{llll}
24 & 23 & 23 & 24 \\
24 & 23 & 23 & 24 \\
24 & 23 & 23 & 24 \\
24 & 23 & 23 & 24
\end{array}\right]-\left[\begin{array}{cccc}
17 & 16 & 17 & 17 \\
16 & 15 & 16 & 16 \\
15 & 14 & 15 & 15 \\
16 & 15 & 19 & 16
\end{array}\right] } \\
& =\left[\begin{array}{llll}
7 & 6 & 6 & 7 \\
8 & 7 & 7 & 8 \\
9 & 9 & 8 & 9 \\
8 & 8 & 4 & 8
\end{array}\right]
\end{aligned}
$$$$
\phi_{3}=\Gamma_{3}-\Psi
$$$$
\begin{aligned}
& =\left[\begin{array}{llll}
20 & 20 & 21 & 20 \\
19 & 19 & 20 & 20 \\
19 & 18 & 19 & 19 \\
19 & 18 & 19 & 18
\end{array}\right]-\left[\begin{array}{llll}
17 & 16 & 17 & 17 \\
16 & 15 & 16 & 16 \\
15 & 14 & 15 & 15 \\
16 & 15 & 19 & 16
\end{array}\right] \\
& =\left[\begin{array}{llll}
3 & 4 & 4 & 3 \\
3 & 4 & 4 & 4 \\
4 & 4 & 4 & 4 \\
3 & 3 & 0 & 3
\end{array}\right]
\end{aligned}
$$

d. The next step is to calculate the covariance value (C), with the following equation:

$$
\begin{aligned}
& \mathrm{C}=\frac{1}{M} \sum_{n=1}^{m} \phi_{n} \phi_{n}^{T}=A A^{T} \\
& \mathrm{~L}=A A^{T} \\
& \mathrm{~L}=\phi_{n}^{T} \phi_{n}
\end{aligned}
$$

Hitung nilai matrik kovarian (C):

$$
\begin{aligned}
& \mathrm{L}=\left[\begin{array}{cccccccccccc}
-10 & -9 & 8 & -8 & 7 & 6 & 6 & 7 & 3 & 4 & 4 & 3 \\
-11 & -10 & -10 & -10 & 8 & 7 & 7 & 8 & 3 & 4 & 4 & 4
\end{array}\right] \\
& \begin{array}{llllllllllll}
-11 & -11 & -11 & -11 & 9 & 9 & 8 & 9 & 4 & 4 & 4 & 4
\end{array} \\
& {\left[\begin{array}{llllllllllll}
-11 & -10 & -13 & -10 & 8 & 8 & 4 & 8 & 3 & 3 & 0 & 3
\end{array}\right.} \\
& x\left[\begin{array}{cccc}
-10 & -11 & -11 & 11 \\
-9 & -10 & -11 & -10 \\
-8 & -10 & -11 & -13 \\
-8 & -10 & -11 & -10 \\
7 & 8 & 9 & 8 \\
6 & 7 & 9 & 8 \\
6 & 7 & 8 & 4 \\
7 & 8 & 9 & 8 \\
3 & 3 & 4 & 3 \\
4 & 4 & 4 & 3 \\
4 & 4 & 4 & 0 \\
3 & 4 & 4 & 3
\end{array}\right]
\end{aligned}
$$




$$
\mathrm{L}=\left[\begin{array}{cccc}
1 & 5 & 3 & -3 \\
0 & 1 & 1 & -1 \\
0 & 2 & 1 & -1 \\
0 & -2 & -1 & -1
\end{array}\right]
$$

e. The next step is to calculate the eigenvalue $(\lambda)$ and eigenvector (v) values of the covariance matrix (C) with the following equation:

$\mathrm{Cx} \mathrm{v}=\lambda_{\mathrm{i}} * \mathrm{v}_{\mathrm{i}}$

Determine the eigenvalue $(\lambda)$ and eigenvector $(\mathrm{v})$ values

$\mathrm{L}=\lambda * \mathrm{v}$

$\mathrm{L} * \mathrm{~V}=\lambda \mathrm{I} * \mathrm{~V}$

$\mathrm{L}-\lambda \mathrm{I}=0$ atau $\lambda \mathrm{I}-\mathrm{L}=0$

Then the eigenvalue $(\lambda)$ can be calculated, $\operatorname{det}(\lambda I-L)=0$

$=\lambda\left[\begin{array}{llll}1 & 0 & 0 & 0 \\ 0 & 1 & 0 & 0 \\ 0 & 0 & 1 & 0 \\ 0 & 0 & 0 & 1\end{array}\right]-\left[\begin{array}{cccc}1 & 5 & 3 & -3 \\ 0 & 1 & 1 & -1 \\ 0 & 2 & 1 & -1 \\ 0 & -2 & -1 & -1\end{array}\right]$

A value will be generated $\lambda=0$ dan $\lambda$ $=1$

$v=\left[\begin{array}{l}v 1 \\ v 2 \\ v 3 \\ v 4\end{array}\right]$

eigenvector ( $v)$ can be generated by substituting the eigenvalue $(\lambda)$ value into the equation $(\lambda \mathrm{I}-\mathrm{L})=1$, for $\lambda=0$, than

$$
\begin{aligned}
& =\left[\begin{array}{cccc}
0-1 & 5 & 3 & -3 \\
0 & 0-1 & 1 & -1 \\
0 & 2 & 0-1 & -1 \\
0 & -2 & -1 & 0-1
\end{array}\right]\left[\begin{array}{l}
v 1 \\
v 2 \\
v 3 \\
v 4
\end{array}\right] \\
& =\left[\begin{array}{l}
0 \\
0 \\
0 \\
0
\end{array}\right]=\left[\begin{array}{cccc}
-1 & 5 & 3 & -3 \\
0 & -1 & 1 & -1 \\
0 & 2 & -1 & -1 \\
0 & -2 & -1 & -1
\end{array}\right] \\
& =\left[\begin{array}{c}
v 1 \\
v 2 \\
v 3 \\
v 4
\end{array}\right]=\left[\begin{array}{cccc}
-v 1 & 5_{v 2} & 3_{v a} & -3_{v 4} \\
v 1 & -v 2 & 1_{v a} & -1_{\mathrm{v} 4} \\
v 1 & 2_{\mathrm{v} 2} & -v 3 & -1_{v 4} \\
v 1 & -2_{\mathrm{v} 2} & -1_{\mathrm{va}} & -v 4
\end{array}\right] \\
& =\left[\begin{array}{l}
0 \\
0 \\
0 \\
0
\end{array}\right]=\text { the resulting eigenvector } \\
& =\left[\begin{array}{l}
-1 \\
0 \\
0 \\
0
\end{array}\right] \text { and }\left[\begin{array}{c}
-3 \\
0 \\
0 \\
0
\end{array}\right] \\
& \lambda=1, \text { than }
\end{aligned}
$$

$$
\begin{aligned}
& =\left[\begin{array}{cccc}
1-1 & 5 & 3 & -3 \\
0 & 1-1 & 1 & -1 \\
0 & 2 & 1-1 & -1 \\
0 & -2 & -1 & 1-1
\end{array}\right]\left[\begin{array}{l}
v 1 \\
v 2 \\
v 3 \\
v 4
\end{array}\right] \\
& =\left[\begin{array}{l}
0 \\
0 \\
0 \\
0
\end{array}\right]=\left[\begin{array}{cccc}
0 & 5 & 3 & -3 \\
0 & 0 & 1 & -1 \\
0 & 2 & 0 & -1 \\
0 & -2 & -1 & 0
\end{array}\right]\left[\begin{array}{l}
v 1 \\
v 2 \\
v 3 \\
v 4
\end{array}\right] \\
& =\left[\begin{array}{llll}
v 1 & 5_{v 2} & 3_{v a} & -3_{\mathrm{v} 4} \\
v 1 & v 2 & 1_{\mathrm{va}} & -1_{\mathrm{v} 4} \\
v 1 & 2_{\mathrm{v} 2} & v 3 & -1_{\mathrm{v} 4} \\
v 1 & -2_{\mathrm{v} 2} & -1_{\mathrm{ra}} & v 4
\end{array}\right]=\left[\begin{array}{l}
0 \\
0 \\
0 \\
0
\end{array}\right] \\
& =\text { the resulting eigenvector } \\
& =\left[\begin{array}{l}
0 \\
0 \\
0 \\
0
\end{array}\right] \text { and }\left[\begin{array}{c}
-3 \\
0 \\
0 \\
0
\end{array}\right]
\end{aligned}
$$

So that the eigenvector generated from the matrix $\mathrm{L}$ is:

$$
=\left[\begin{array}{cccc}
-1 & -3 & 0 & -3 \\
0 & 0 & 0 & 0 \\
0 & 0 & 0 & 0 \\
0 & 0 & 0 & 0
\end{array}\right]
$$

f. The next step is to find the eigenface value using the following equation:

$\mu_{\mathrm{i}}=\sum_{m=1}^{m} v_{i k} \phi_{k}$

$\mathrm{L}=1,,,, \mathrm{M}$

$\mu_{1}=v \times \phi_{1}$

$=\left[\begin{array}{cccc}-1 & -3 & 0 & -3 \\ 0 & 0 & 0 & 0 \\ 0 & 0 & 0 & 0 \\ 0 & 0 & 0 & 0\end{array}\right]\left[\begin{array}{cccc}-10 & -9 & 8 & -8 \\ -11 & -10 & -10 & -10 \\ -11 & -11 & -11 & -11 \\ -11 & -10 & -13 & -10\end{array}\right]$

$=\left[\begin{array}{cccc}10 & 27 & 0 & 24 \\ 0 & 0 & 0 & 0 \\ 0 & 0 & 0 & 0 \\ 0 & 0 & 0 & 0\end{array}\right]$

$\mu_{2}=v \times \phi_{2}$

$=\left[\begin{array}{cccc}-1 & -3 & 0 & -3 \\ 0 & 0 & 0 & 0 \\ 0 & 0 & 0 & 0 \\ 0 & 0 & 0 & 0\end{array}\right]\left[\begin{array}{llll}7 & 6 & 6 & 7 \\ 8 & 7 & 7 & 8 \\ 9 & 9 & 8 & 9 \\ 8 & 8 & 4 & 8\end{array}\right]$

$=\left[\begin{array}{cccc}-7 & -18 & 0 & -21 \\ 0 & 0 & 0 & 0 \\ 0 & 0 & 0 & 0 \\ 0 & 0 & 0 & 0\end{array}\right]$

$\mu_{2}=v \times \phi_{2}$

$=\left[\begin{array}{cccc}-1 & -3 & 0 & -3 \\ 0 & 0 & 0 & 0 \\ 0 & 0 & 0 & 0 \\ 0 & 0 & 0 & 0\end{array}\right]\left[\begin{array}{llll}3 & 4 & 4 & 3 \\ 3 & 4 & 4 & 4 \\ 4 & 4 & 4 & 4 \\ 3 & 3 & 0 & 3\end{array}\right]$

$=\left[\begin{array}{cccc}-3 & -12 & 0 & -9 \\ 0 & 0 & 0 & 0 \\ 0 & 0 & 0 & 0 \\ 0 & 0 & 0 & 0\end{array}\right]$ 
With the eigenface value, Figure 1, Figure 2, Figure 3, it can be determined that with other eigenface values can be determined based on the eigenface matrix values obtained from each image. Based on the values obtained from Figures 1, 2, and 3 , it can be concluded that the eigenface method is able to recognize faces with a presentation value of $80 \%$.

\section{CONCLUSION}

Digital images can be used to insert information to be conveyed to others. information contained in the image can be tapped and can be manipulated. Therefore, it is necessary after detecting image similarities, we can find out whether the information has changed or not. If the value contained in the image is different from the value of the previous image, then the information in the image has been changed. using the Eigen Face method can help to find out the information in an image, the higher and farther the value changes from the image, it can be concluded that the information contained in the image is no longer authentic.

\section{BIBLIOGRAPHY}

[1] Q. Mutiara and E. Prasetyo, "LBPH pada Sistem Pengenalan Wajah," vol. 18, 2019.

[2] Rudi Kurniawan and A. Zulius, "Smart Home Security Menggunakan Face Recognition Dengan Metode Eigenface Berbasis Raspberry Pi," J. Sustain. J. Has. Penelit. dan Ind. Terap., vol. 8, no. 2, pp. 48-56, 2019, doi: 10.31629/sustainable.v8i2.1484.

[3] A. Zein, "Pendeteksian Multi Wajah dan Recognition Secara Real Time Menggunakan Metoda Principal Component Analysis (PCA) dan Eigenface," Esit, vol. 12, no. 1, pp. 1-7, 2018.

[4] R. B. Pratama, "Penerapan Metode Eigenface pada Sistem Parkir Berbasis Image Processing," $J$. Disprotek, vol. 9, no. 2, pp. 86-96, 2018, doi: 10.34001/jdpt.v9i2.801.

[5] M. H. Hersyah, F. Firdaus, and A. S. Putri, "Penerapan Face Recognition Pada Sistem Starter Mobil Otomatis Menggunakan Metode Eigenface Berbasis Mini PC," J. Teknoif, vol. 6, no. 2, pp. 81-89, 2018, doi: 10.21063/jtif.2018.v6.2.81-89.

[6] Z. N. Abdillah, "Implemantasi Pengenalan Wajah Dengan Metode Eigenface Pada Sistem Password Laptop," JURIKOM (Jurnal Ris. Komputer), vol. 5, no. 3, pp. 278-283, 2018.

[7] Y. Wihardi, H. Siregar, and A. Mulyawan, "TEMU KEMBALI CITRA BERBASIS KONTEN PADA CITRA TEMU KEMBALI CITRA BERBASIS KONTEN PADA CITRA," vol. 12, no. 1, pp. 34-46, 2018.

[8] Johan Wahyudi and Ihdahubbi Maulida, "Pengenalan Pola Citra Kain Tradisional Menggunakan Glcm Dan Knn," J. Teknol. Inf. Univ. Lambung Mangkurat, vol. 4, no. 2, pp. 43-48, 2019, doi: 10.20527/jtiulm.v4i2.37.

[9] H. Sulaiman, Z. Zainuddin, and S. Sahibu, "Sistem Deteksi Wajah Untuk Identifikasi Kehadiran Mahasiswa Dengan Menggunakan Metode Eigenface Pca," J. Ris. 
Inform., vol. 1, no. 2, pp. 97-106, 2019, doi: 10.34288/jri.v1i2.36.

[10] I. Simanjuntak, "Rancang Bangun Kunci Otomatis Sepeda Motor Berbasis Face Recognition Dengan Metode Eigenfaces OpenCV," J. Tek. Elektro ITP, vol. 8, no. 2, pp. 122-128, 2019, doi: 10.21063/jte.2019.3133821. 